\title{
ANALISIS PREFERENSI NASABAH DALAM MEMILIH PT. BPRS BHAKTI SUMEKAR KANTOR CABANG PRATAMA GILI GENTING
}

\author{
Yusni Bella Mufida1 \\ Dharma Arif Maulana2 \\ Jurusan Perbankan Syariah, Fakultas Ekonomi dan Bisnis Islam, IAIN Madura, \\ Pamekasan, Indonesia. ${ }^{1}$ \\ Jurusan Ekonomi Syariah, Fakultas Ekonomi dan Bisnis Islam, IAIN Madura, Pamekasan, \\ Indonesia. ${ }^{2}$ \\ Email: yusnibellamufida@gmail.com,Dharmaarifmaulana@gmail.com
}

\begin{abstract}
Introduction: preference when choosing a banking institution to transact have a diversity of percepation. The lack of public knowledge of Islamic banking institutions is a fundamental problem for Bank Pembiayaan Rakyat Syariah (BPRS) as a sharia banking institution on the island of Gili Genting.

Methods: In this study, the research design used descriptive research with a quantitative approach. The sampling technique used is the scientific sampling technique, that is, anyone who happens to meet, if it is seen that the person found is suitable as a data source. The data presented in this study include the mean, median, mode, tables, graphs, pie charts. The data analysis method used is descriptive analysis processed with SPSS.

Results: The results of this study can be concluded that: First, the level of customer knowledge about the operational system of BPRS Bhakti Sumekar, Gili Genting Pratama Branch Office based on sharia principles is very good with an average value of 4.32 , the information received by customers is very good with an average value the average is 4.23 , and the tendency of customers' preference for BPRS Bhakti Sumekar, Gili Genting Pratama Branch Office is very good with an average value of 4.28. Second, the reasons for costumers to choose BPRS Bhakti Sumekar at the Gili Genting Pratama Branch office are very diverse, as well as the products offered, not all of them have high demand, $36 \%$ of costumers do not only transact at one bank, but have an account at another bank,

Conclusions and suggestions: Customer preference for BPRS Bhakti Sumekar, Gili Genting Pratama Branch Office is in the very good category with a range of scores (average between $4.20-5.00$ or a score between $81 \%-100 \%$ ).
\end{abstract}

Keywords: Preference, Costumer, BPRS. 


\section{PENDAHULUAN}

Perkembangan perbankan syariah di Indonesia memuncak pada tahun 2008, dibuktikan dengan ditetapkannya undang-undang nomo 21 tahun 2008 tentang perbankan syariah. ${ }^{1}$ Undang-undang ini sejalan dengan tujuan pembangunan nasional Indonesia untuk mencapai masyarakat adil dan makmur berdasarkan demokrasi ekonomi, dengan mengembangkan sistem ekonomi yang berlandaskan pada nilai keadilan, kebersamaan, pemerataan, dan kebermanfaatan yang sesuai dengan prinsip syariah. $^{2}$

Bank Pembiayaan Rakyat Syariah (BPRS) merupakan salah satu lembaga perbankan syariah yang melaksanakan kegiatan berdasarkan prinsip syariah, yang dalam kegiatannya tidak memberikan jasa dalam lalu lintas pembayaran. ${ }^{3}$ Kegiatan BPRS jauh lebih sempit dibandingkan dengan bank umum, karena BPRS dilarang menerima simpanan giro, kegiatan valas, dan peransurasian. ${ }^{4}$

Pada tahun 2018, BPRS Bhakti Sumekar meresmikan kantor cabang pratama di pulau gili genting yang terletak di Dusun Manding, Desa Aenganyar, Kecamatan Gili Genting. Hal ini bertujuan untuk memberikan kemudahan masyarakat sekitar untuk melakukan transaksi yang berhubungan dengan keuangan. Namun sebagai lembaga perbankan syariah pertama di pulau ini dalam perkembangannya memiliki masalah mendasar yakni, Pemahaman masyarakat akan lembaga perbankan syariah dengan perbankan konvensional dianggap sama. Hal ini mengindikasikan bahwa masih banyak masyarakat yang belum mengetahui tentang lembaga perbankan syariah.

Masyarakat pulau Gili Genting memiliki persepsi untuk memilih lembaga perbankan yang dapat membantu dalam aspek keuangan dan perekonomian dalam kehidupannya. Dalam hal ini BPRS sebagai lembaga perbankan syariah memiliki tugas untuk bagaimana memberikan edukasi secara menyeluruh dan pemahaman terhadap perilaku masyarakat sebagai konsumen atau nasabah untuk memilih (prefer) BPRS sebagai lembagai perbankan syariah yang utama.

\section{TINJAUAN PUSTAKA}

\footnotetext{
${ }^{1}$ Muslikhin, M., Kinanti, R. A., Muhtadi, R., \& Fudholi, M. (2020). Pemeriksaan Empiris Pada Pengaruh Kinerja Sosial Terhadap Profitabilitas Di Bank Syariah. Ulumuna: Jurnal Studi Keislaman, 6(1), 72-84.

2 Khotibul Umam, Perbankan Syariah (Dasar-dasar dan Dinamika Perkembangannya di Indonesia) (Jakarta : PT Raja Grafindo Persada, 2016),12.

${ }^{3}$ Sari, L., Muhtadi, R., \& Mansur, M. (2020). Analisis Manajemen Sumber Daya Insani Pada Bank Pembiayaan Rakyat Syariah. Ar-Ribhu: Jurnal Manajemen Dan Keuangan Syariah, 1(2), 158-172.

${ }^{4}$ Herry, E., Permana, P. Y. E., Aji, W. B., \& Muhtadi, R. (2019). Total Quality Management Development and Sharia Governance Efforts in Sharia Micro Financial Institutions to Improve Market Share. IJIEEB International Journal of Integrated Education, Engineering and Business eISSN 2615-1596 pISSN 2615-2312, 2(1), 27-35.
} 


\section{Preferensi dalam Ekonomi Islam}

Preferensi dalam Islam dikaji dimana seseorang dalam menggunakan kekayaan harus berhati-hati, yang terpenting dalam hal ini adalah cara penggunaan yang harus diarahkan pada pilihan-pilihan(preferensi) yang mengandung maslahah (baik dan manfaat). Agar kekayaan atau harta tersebut dapat memberikan manfaat untuk kesejahteraan bagi individu tersebut. ${ }^{5}$

Preferensi seseorang terhadap suatu barang atau jasa sangat beragam dimana sangat dipengaruhi oleh tingkat keyakinan dan pemahaman penggunannya. Prferensi seorang muslim akan sangat jauh berbeda dengan preferensi seorang non-muslim. Dalma Islam sudah jelas dan cukup rinci mengklasifikasikan nama barang halal dan barng buruk.

Preferensi dalam Islam disini dikaitkan dengan teori konsumsi dalam Islam, karena dalam pembahasan preferensi dasarnya adalah perilaku konsumen. Sebuah mekanisme yang tanoa disadari, bermacam-macam komodiit dan jasa yang tersedia, tetapi manusia berhasil untuk memilih rangkaian komoditi dan jasa tersebut.

Preferensi konsumen dapat dlihat melalui unsur-unsur berikut yakni: Pertama, Pengetahuan, pengetahuan adalah informasi yang telah diinterpretasikan oleh seseorang dengan mengunnakan sejarah, pengalaman, dan skema interpretasi yang dimilikinya. Kedua, Informasi, tujuan pemasaran suatu perusahaan adalah memenuhi dan melayani kebutuhan serta keinginan konsumen, namun untuk mengetahuinya keinginan dna kebutuhan konsumen tidaklah mudah. Oleh karena itu untuk mengetahui persepsi, preferensi serta perilkau belanja pelanggan yang menjadi sasaran mereka. Konsuen memproses informasi tentang produk didasarkan pada pilihan mereka untuk membuat keputusan akhir. Timbulnya pembelian suatu produk terlihat dimana konsumen mempunyai kebutuhan yang ingin dipuaskan. Konsumen akan mencari informasi tentang manfaat produk dan selanjutnya mengevaluasi atribut produk tersebut. Konsumen akan memberikan bobot yang berbeda untuk setiap atribut produk sesuai dengan kepentingannya, dari sini akan menim bulkan preferensi konsumen terhadap merk yang ada, Ketiga kecenderungan pilihan, preferensi seseorang terhadap suatu objek adalah keinginan atau kecenderungan seseorang untuk memilih atau tidak memilih objek tersebut sejauh mana seseorang lebih suka memfokuskan perhatian. Ada 2 arah yang berlawanan kemana seseorang dapat memfokuskan perhatian, yaitu kea rah dunia luar dirinya (extroversion). Orang yang lebih extroversion cenderung untuk memfokuskan perhatiannya kepada dunia luar dirinya, yaiut terhadap orang-orang di sekelilingnya dan kejadian-kejadian di sekitarnya. Orang extrovert lebih menyukai berkomunikasi melalui kata-kata dari pada dengan tulisan. Mereka akan lebih mudah memahami sesuatu setelah mengalaminya terlebih dahulu, oleh sebab itu mereka adalah orang yang menyukai

${ }^{5}$ Rosyadah, P. C., Arifin, N. R., Muhtadi, R., \& Safik, M. (2020). Factors That Affect Savings In Islamic Banking. ALARBAH: Journal of Islamic Finance and Banking, 2(1), 33-46. 
tindakan daripada ide/pemikiran (action oriented). Selanjutnya, orang yang lebih suka menyukai introversion cenderung untuk memfokuskan perhatiannya ke dalam dunia pemikirannya sendiri. pada saat mereka sedang melakukan introversion, mereka bergairah terhadap apa yang sedang bergejolak di dalam pikirannya dan kondisi inilah yang akan menimbulkan kecenderungan untuk mengarahkan perhatian dan energinya terhadpa pemikiran tersebut. Orang yang introvert cenderung untuk merasa lebih nyaman dan tertarik apabila menghadapi suatu pekerjaan yang menuntut pembahasan dan epmikiran yang dapat dilakukan sendiri secara tenang. Mereka cenderung untuk mencoba mengerti dan memahami sesuatu sebelum mencoba atau mengalaminya. Oleh karena itu, mereka cenderung berfikir terlebih dahulu sebelum mengambil tindakan.

Proses mengambil keputusan, proses pengambilan untuk membeli atau menggunakan suatu produk, konsumen harus melalui 5 tahao, yaitu: pertama, Pengenalan kebutuhan, merupakan tahap dimana pembeli mengenali masalah atau kebutuhannya, Kedua Pencarian informasi, setelah mengetahui apa yang dibutuhkannnya, maka selanjutnya konsumen berusaha mencari informasi lebih banyak tentang hal yang berkaitan dengan kebutuhannya, Ketiga Evaluasi alternative, merupakan tahap dimana konsumen memperoleh informasi tentang suatu objek dan membuat penilaian akhir. Pada tahap ini konsumen menyempitkan pilihan hingga alternated yang dipilih berdasarkan besarnya kesesuaian antara manfaat yang diinginkan yang bisa diberikan ileh produk yang tersedia, Keempat Keputusan pembelian, merupakan tahapan dimana konsumen telah memiliki pilihan dan siap melakukan transaksi pembelian. Pada keputusan pembelian ini terdapat 2 faktor yang dapat muncul yaitu antara niat unutk membeli dan keputusan pembelian. Faktor pertama adalah berasal dari sikap orang lain yang akan mepengaruhi keputusan pembelian, faktor yang kedua adalah faktro situasi yang tidak diharapkan, kejadian-kejadian yang tidak diharapkan mungkin karna mengubah niat untuk membeli, Kelima Perilaku pasca pembelian, merupakan tahapan dimana konsumen setelah melakukan pembelian akan mengalami 2 kemungkinan yaitu kepuasan dan ketidak puasan atas pilihan yang diambilnya. Keputusan pembelian barang atau jasa seringkali melibatkan 2 pihak atau lebih. Umumnya ada 5 peranan yang terlibat yakni pemrakarsa (initiator), pembawa pengaruh (influencer), pengambil keputusan (decider), pembeli (buyer), pemakai (user). ${ }^{6}$

\section{Persepsi}

Persepsi didefinisikan sebagai proses psikologis dimana individu menyeleksi, mengorganisasikan dan menginterpretasikan stimuli menjadi sesuatu yang bermakna. Proses persepsi diawali oleh stimuli yang mengenai indera konsumen. Stimuli yang merupakan segala sesuatu yang mengenai indera dan menimbulkan persepsi bisa bermacam-macam bentuknya, misalnya segala sesuatu yang bisa dicium, dilihat, di

\footnotetext{
${ }^{6}$ Tatik Suryani, perilaku Konsumen: Implikasi pada strategi pemasaran (Yogyakarta: Graha IImu, 2012 ), 13.
} 
dengar, dan diraba. Stimuli ini akan mengenai organ yang disebut sebagai sensor receptor (organ manusia yang menerima input stimuli atau indera). ${ }^{7}$

Seleski sebagai proses persepsi diawali oleh adanya stimuli yang mengenai panca indera yang disebut sebagai sensasi. Dalam konteks perilaku konsumen stimuli yang berpengaruh pada persepsi konsumen adalah semua usaha yang dilakukan oleh pemasar melalui strategi pemasarannya.

Setelah memilih stimuli, konsumen akan mengorganisasikannya dengan cara mengelompokkan dan menghubung-hubungkan dengan stimuli lain agar dapat diinterpretasikan, sehingga mempunyai makna. Adapun prinsip-prinsip dasar dalam pengorganisasian yakni a) gambar dan latar belakang (Figure and Ground), agar stimuli diperhatikan mudah diberi makna, konsumen akan menghubungkan dan mengaitkan antara gambar dengan dasar, antara apa yang ada dengan konteksnya sehingga mempunyai makna. b) kecenderungan untuk menutup atau menyelesaikan (Closure), menurut psikologi Gestalt Konsumen cenderung menanggapi secara keseluruhan, oleh karena itu ada dorongan pada konsumen untuk mengisi kekurangan dari stimuli yang ada agar menjadi utuh. c) pengelompokkan (Grouping), konsumen cenderung mengelompokkan objek yang mempunyai kemiripan menjadi satu kelompok.

Setelah konsumen mengorganisir stimuli dan mengaitkannya dengan informasi yang dimiliki, maka agar stimuli tersebut mempunyai makna, konsumen menginterpretasikan atau memberi arti stimuli tersebut. Pada saat interpretasi ini konsumen secara sadar atau tidak sadar akan mengait-ngaitkan dengan semua informasi yang dimilikinya agar mampu memberikan makna yang tepat. Dalam proses ini penglaman dan kondisi psikologis konsumen seperti kebutuhan, harapan, dan kepentingan akan berperan penting dalam menginterpretasikan stimuli.

\section{Bank Pembiayaan Rakyat Syariah (BPRS)}

Bank Pembiayaan Rakyat Syariah (BPRS) merupakan salah satu jenis lembaga perbankan syariah yang berlaku di Indonesia. ${ }^{8}$ Dalam kegiatannya BPRS tidak memberikan jasa dalam lalu lintas pembayaran. Berbeda dengan Bank Umum Syariah (BUS), BPRS tidak diperkenankan untuk membuka kantor cabang, kantor perwakilan, dan jenis kantor lainnya di luar negeri. Oleh karenanya, BPRS berfungsi sebagai pelaksana dari Bank Umum yang beroperasi di tingkat regional saja. Jenis produk yang ditawarkan oleh BPRS relatif sempit jika dibandingkan dengan Bank Umum, bahkan ada beberapa jenis

\footnotetext{
${ }^{7}$ Tatik Suryani, Perilaku Konsumen di Era Internet (Yogyakarta: Graha IImu, 2013), 75.

${ }^{8}$ Ismail, Manajemen Perbankan dari Teori Menuju Aplikasi (Jakarta: Prenada Media Group, 2010), 15. Lihat Juga, Subaida, S., Mansur, M., \& Muhtadi, R. (2020). Strategi Keandalan Pelayanan Pada Pt. Bprs Sarana Prima Mandiri. Ar-Ribhu: Jurnal Manajemen Dan Keuangan Syariah, 1(2), 265-274. Dan Siyah, S., Mansur, M., \& Muhtadi, R. (2020). Analisis Sistem Rekrutmen Dan Pelatihan Dalam Meningkatkan Kinerja Karyawan. Ar-Ribhu: Jurnal Manajemen dan Keuangan Syariah, 1(2), 188-203.
} 
jasa bank yang tidak boleh diselenggarakan oleh BPRS seperti pembukaan rekening giro serta ikut kliring. ${ }^{9}$

\section{METODE PENELITIAN}

Penelitian ini menggunakan mix methode yang berarti menggunakan pendekatan kuantitatif dan kualitatif. Penelitian ini menggunakan metode deskriptif dengan pendekatan kuantitatif. Penelitian deskriptif tidak dimaksudkan untuk menguji hipotesis tertentu, tetapi hanya menggambarkan apa adanya tentang suatu variabel, gejala atau keadaan. Penelitian kuantitatif yaitu penelitian dengan melibatkan perhitungan atau angka-angka dan hasil dari analisis kuantitatif cenderung membuktikan maupun memperkuat teori-teori yang sudah ada. ${ }^{10}$

Dalam penelitian ini juga terdapat data berupa informasi kualitatif. Hal ini dimaksudkan untuk mencocokkan antara realita yang ada dalam masyarakat tersebut dengan teori yang berlaku dengan menggunakan metode deskriptif, yaitu data-data yang dikumpulkan berupa kata-kata. ${ }^{11}$

\section{HASIL DAN PEMBAHASAN}

\section{Preferensi Nasabah Terhadap BPRS Bhakti Sumekar Kantor Cabang Pratama Gili Genting}

Preferensi adalah langkah pertama untuk menjelaskan alasan seseorang lebih suka suatu jenis produk dari jenis produk yang lainnya. Preferensi mempunyai makna pilihan atau memilih.

Berdasarkan hasil perhitungan melalui analisis deskriptif maka diperoleh sebagai berikut: (1)Pengetahuan, Berdasarkan hasil analisis tentang pengetahuan nasabah menjelaskan bahwa pengetahuan dalam kategori sangat tahu rata-rata 4,32, dan rata-rata setiap pernyataan sebagian besar dalam kategori sangat tahu dengan nilai di atas 4,21. Artinya pengetahuan nasabah terhadap lembaga keuangan syariah BPRS Bhakti Sumekar Kantor Cabang Pratama Gili Genting yang menerapkan sistem perbankan syariah sangat baik. Hal itu berarti bahwa nasabah memiliki pengetahuan yang tinggi terhadap pengetahuan operasional yang diterapkan di BPRS Bhakti Sumekar Kantor Cabang Pratama Gili Genting sehingga diperlukan strategi bagi BPRS untuk mempertahankan dan mengembangkan pengetahuan nasabah tentang sistem operasional yang diterapkan BPRS. (2) Informasi yang diterima, konsumen memperoleh informasi dari sumber pribadi, komersial, public, dan pengalaman, namun yang paling efektif adalah sumber pribadi dalam mempengaruhi pembelian. Ketika banyak informasi yang diperoleh maka

\footnotetext{
${ }^{9}$ Andri Soemitra, Bank dan Lembaga Keuangan SYariah (Jakarta: Kencana, 2017), 44.

10 Suharsimi Arikunto, Manajemen Penelitian (Jakarta: Rineka Cipta, 2010), 234.

11 Lexy J. Moloeg, Metodologi Penelitian Kualitatif (Bandung: Remaja Rosda Karya, 2005), 11.
} 
semakin bertambah pula kesadaran dan pengetahuan konsumen mengenai produk. Sama halnya dengan nasabah di BPRS Bhakti Sumekar Kantor Cabang Pratama Gili Genting, bahwa informasi yang diterima nasabah juga melalui berbagai sumber untuk menentukan nasabah dalam memilih lembaga keuangan syariah agar kebutuhan dirinya terpenuhi. Berdasarkan hasil analisis tentang informasi yang diterima nasabah tentang BPRS Bhakti Sumekar Kantor Cabang Pratama Gili Genting menjelaskan bahwaunsur informasi yang diterima dalam kategori sangat baik dengan rata-rata sebesar4,23. Artinya iformasi yang diterima nasabah BPRS Bhakti Sumekar Kantor Cabang Pratama Gili Genting dalam menerima informasisangat baik. (3). Kecenderungan pilihan, preferensi seseorang terhadap suatu objek adalah keinginan atau kecenderungan seseorang untuk memilih atau tidak memilih objek tersebut sejauhmana seseorang lebih suka memfokuskan perhatian. Di mana nasabah BPRS Bhakti Sumekar Kantor Cabang Pratama Gili Genting kecenderungannya akan condong atau mengarah pada suatu lembaga keuangan syariah yang sesuai dengan pilihan dan kebutuhannya. Berdasarkan hasil analisis tentang kecenderungan pilihan menjelaskan bahwa kecenderungan pilihan nasabah dalam kategorisangat baik yaitu sebesar4,28, dan rata-rata setiap pernyataan sebagian besar dalam kategori sangat baik dengan nilai di atas4,21. Artinya bahwa kecenderungan pilihan nasabah dalam memilih BPRS Bhakti Sumekar Kantor Cabang Pratama Gili Genting sangat baik.

\section{Alasan Nasabah Memilih BPRS Bhakti Sumekar Kantor Cabang Pratama Gili Genting}

Preferensi adalah pilihan-pilihan yang dibuat oleh para konsumen atas produkproduk yang dikonsumsi. Konsumen akan menentukan produk-produk apa yang mereka beli dari pendapatan mereka yang terbatas. Berdasarkan hasil analisis tentang alasan nasabah memilih BPRS Bhakti Sumekar Kantor Cabang Pratama Gili Genting, terdapat beberapa alasan yang bervariasi dari setiap responden, peneliti mengkategorikan alasanalasan nasabah dalam memilih BPRS Bhakti Sumekar Kantor Cabang Pratama Gili Genting. Responden yang menyatakan alasan karena faktor syariah berjumlah41 orang, alasan karena lokasi yang strategis berjumlah 22 orang, alasan karena mendapatkan tawaran dari pegawai BPRS Bhakti Sumekar Kantor Cabang Pratama Gili Genting berjumlah 19 orang, alasan karena cara menabung yang diberikan oleh BPRS Bhakti Sumekar Kantor Cabang Pratama Gili Genting lebih mudah (sistem jemput bola) sebanyak 14 orang, ajakan dari teman responden berjumlah 5 orang, alasan karena ajakan dari kerabat responden berjumlah 10 orang, dan alasan karena mendapat sosialisasi di sekolah responden sebanyak 4 orang. Jumlah total dari alasan-alasan tersebut adalah 115 alasan, hal itu terjadi karena terdapat beberapa responden menjawab lebih dari satu alasan memilih BPRS Bhakti Sumekar Kantor Cabang Pratama Gili Gentingg.Hal ini menunjukkan bahwa alasan yang paling dominan adalah faktor syariah. 
Berdasarkan hasil penelitian mengenai produk-produk apa saja yang diminati nasabah BPRS Bhakti Sumekar Kantor Cabang Pratama Gili Genting bahwa tidak semua produk-produk yang terdapat di BPRS Bhakti Sumekar Kantor Pusatyang diterapkan di Kantor Cabang. Responden yang memilih tabungan barokah berjumlah 61 orang, tabungan simpel berjumlah 16 orang, responden yang meminatiproduk tabungan umroh berjumlah 12 orang, responden yang meminatiproduk tabungan haji berjumlah 10 orang. Dari data yang diperoleh peneliti, produk pembiayaan yang tersedia di BPRS Bhakti Sumekar Kantor Cabang Pratama Gili Genting tidak terlalu diminati oleh nasabah yang menjadi responden dalam penelitian ini,responden yang meminatiprodukpembiayaan serbaguna berjumlah 2 orang, dan memilih gadai emas berjumlah 7 orang. Sedangkan tidak ada responden yang menjadi nasabah pada produk pembiyaan elektronik dan produk pembiayaan sepeda motor. Hal ini menunjukkan bahwa produk yang paling diminati hanya produk tabungan barokah sehingga perlu adanya peningkatan strategi pemasaran bagi BPRS Bhakti Sumekar Kantor Cabang Pratama Gili Genting untuk memasarkan produk-produk yang lain sehingga minat nasabah pada produk yang lain menjadi besar khususnya pada produk-produk pembiayaan.

Berdasarkan hasil penelitian tentang apakah nasabah BPRS Bhakti Sumekar Kantor Cabang Pratama Gili Genting bertransaksi di bank lain, responden yang hanya menjadi nasabah di BPRS Bhakti Sumekar Kantor Cabang Pratama Gili Genting berjumlah 29 orang, responden yang memiliki rekening di BRI berjumlah 41 orang, responden yang memiliki rekening di BCA berjumlah 14 orang, responden yang memiliki rekening di BNI berjumlah 13 orang, responden yang memiliki rekening di BRI Syariah berjumlah 3 orang, dan tidak ada responden yang memiliki rekening di BNI Syariah.. Hal ini menunjukkan bahwa nasabah banyak yang menggunakan bank lain untuk bertransaksiyaitu di bank BRI. Artinya banyak nasabah menggunakan lembaga keuangan perbankan lain khususnya di BRI karena BRI sudah lebih dulu hadir di kalangan masyarakat Gili Genting untuk bertransaksi sehingga memunculkan persaingan usaha bagi BPRS Bhakti Sumekar Kantor Cabang Pratama Gili Genting.

Berdasarkan hasil penelitian tentang harapan nasabah akan keberadaan BPRS Bhakti Sumekar Kantor Cabang Pratama Gili Genting di Kecamatan Gili Genting, Harapan responden agar BPRS Bhakti Sumekar Kantor Cabang Pratama Gili Genting semakin maju berjumlah 26, Harapan responden agar BPRS Bhakti Sumekar Kantor Cabang Pratama Gili Genting semakin bermanfaat untuk masyarakat Gili Genting berjumlah 32, harapan agar mempermudah masyarakat Gili Genting dalam bertransaksi di lembaga keuangan syariah berjumlah 22, harapan dapat menambah ilmu pengetahuan dan teknologi berjumlah 4, harapan agar pelayanannya semakin baik berjumlah 17, dan harapan agar kebutuhan masyarakat Gili Genting pada lembaga keuangan syariah dapat terpenuhi berjumlah 13. Jumlah keseluruhan dari harapan-harapan nasabah yaitu sebanyak 114, di mana terdapat beberapa nasabah yang memiliki dua harapan atau lebih akan keberadaan BPRS Bhakti 
Sumekar Kantor Cabang Pratama Gili Genting. Dari data tersebut harapan yang paling dominan yaitu harapan nasabah bahwa BPRS Bhakti Sumekar Kantor Cabang Pratama Gili Genting akan semakin bermanfaat untuk masyarakat Gili Genting. Artinya nasabah mempunyai harapan- harapan besar pada BPRS Bhakti Sumekar Kantor Cabang Pratama Gili Genting khususnya untuk masyarakat Kecamatan Gili Genting itu sendiri.

\section{KESIMPULAN}

Preferensi nasabah terhadap BPRS Bhakti Sumekar Kantor Cabang Pratama Gili Genting berada dalam kategori sangat baik dengan rentang nilai (rata-rata antara 4,205,00 atau skor antara 81\%-100\%) dengan rincian rata-rata per dimensi yakni, a) Pengetahuan berada dalam kategori sangat baik sebesar 4,32 atau skor 86\%; b) Informasi yang diterima berada dalam kategori sangat baik sebesar 4,23 atau skor $84 \%$; dan c) Kecenderungan pilihan berada dalam kategori sangat baik sebesar 4,28 atau skor 85\%, artinya preferensi nasabah BPRS Bhakti Sumekar Kantor Cabang Pratama Gili Genting dalam unsur pengetahuan, informasi yang diterima dan kecenderungan pilihan terhadap BPRS Bhakti Sumekar Kantor Cabang Pratama Gili Genting diterima dengan sangat baik dan nasabah juga memiliki pilihan yang baik dengan berbagai alasan, diantaranya adalah adanya kemudahan dalam bertransaksi di BPRS Bhakti Sumekar Kantor Cabang Pratama Gili Genting. Tingginya preferensi nasabah terhadap BPRS Bhakti Sumekar Kantor Cabang Pratama Gili Genting dilatarbelakangi oleh beberapa alasan nasabah dalam memilih BPRS Bhakti Sumekar Kantor Cabang Pratama Gili Genting untuk bertransaksi di lembaga keuangan, diantaranya adalah faktor syariah yang diterapkan di BPRS Bhakti Sumekar Kantor Cabang Pratama Gili Genting.

\section{DAFTAR PUSTAKA}

Andri Soemitra, Bank dan Lembaga Keuangan Syariah (Jakarta: Kencana, 2017)

Herry, E., Permana, P. Y. E., Aji, W. B., \& Muhtadi, R. (2019). Total Quality Management Development and Sharia Governance Efforts in Sharia Micro Financial Institutions to Improve Market Share. IJIEEB International Journal of Integrated Education, Engineering and Business eISSN 2615-1596 pISSN 2615-2312, 2(1), 27-35.

Ismail, Manajemen Perbankan dari Teori Menuju Aplikasi (Jakarta: Prenada Media Group, 2010)

Khatibul Umam, Perbankan Syariah (Dasar-dasar dan Dinamika Perkembangannya di Indonesia) (Jakarta: PT. Raja Grafindo Persada, 2016).

Lexy J. Moleog, Metodologi Penelitian Kualitatif (Bandung: Remaja Rosda Karya, 2005) 
Sari, L., Muhtadi, R., \& Mansur, M. (2020). Analisis Manajemen Sumber Daya Insani Pada Bank Pembiayaan Rakyat Syariah. Ar-Ribhu: Jurnal Manajemen Dan Keuangan Syariah, 1(2), 158-172.

Muslikhin, M., Kinanti, R. A., Muhtadi, R., \& Fudholi, M. (2020). Pemeriksaan Empiris Pada Pengaruh Kinerja Sosial Terhadap Profitabilitas Di Bank Syariah. Ulumuna: Jurnal Studi Keislaman, 6(1), 72-84.

Siyah, S., Mansur, M., \& Muhtadi, R. (2020). Analisis Sistem Rekrutmen Dan Pelatihan Dalam Meningkatkan Kinerja Karyawan. Ar-Ribhu: Jurnal Manajemen Dan Keuangan Syariah, 1(2), 188-203.

Subaida, S., Mansur, M., \& Muhtadi, R. (2020). Strategi Keandalan Pelayanan Pada Pt. Bprs Sarana Prima Mandiri. Ar-Ribhu: Jurnal Manajemen Dan Keuangan Syariah, 1(2), 265-274.

Suharsimi Arikunto, Manajemen Penelitian (Jakarta: Rineka Cipta, 2010)

Syofian Siregar, Metode Penelitian Kuantitatif (Dilengkapi dengan Perbandingan Perhitungan Manual \& SPSS) (Jakarta: Penamedia Group, 2013)

Tatik Suryani, Perilaku Konsumen: Implikasi pada strategi pemasaran, (Yogyakarta: Graha Ilmu, 2012)

Tatik Suryani, Perilaku Konsumen di Era Internet (Yogyakarta: Graha Ilmu, 2013)

Khairul Amri, Intan Qurratul Aini dan Julianty, Preferensi Nasabah Memilih Produk Pembiayaan Bank Aceh Syariah di Kota Banda Aceh, Jurnal Samudera Ekonomi dan Bisnis, Vol.9, No.1, Januari 2018.

Rahmadani, Analisis Faktor-faktor yang mempengaruhi preferensi Masyrakat Terhadap Bank Syariah (Studi Kasus Perumahan Setia Kota Melati Tembung), UIN SUMATERA UTARA MEDAN: Medan, 2019, Skripsi.

Rosyadah, P. C., Arifin, N. R., Muhtadi, R., \& Safik, M. (2020). Factors That Affect Savings In Islamic Banking. AL-ARBAH: Journal of Islamic Finance and Banking, 2(1), 33-46.

Ojk.go.id./id/kanal/syariah/tentang-syariah/pages/PBS-dan-kelembagaan.aspx 